\title{
Temozolomide sensitivity of malignant glioma cell lines - a systematic review assessing consistencies between in vitro studies
}

Michael T. C. Poon ${ }^{1,2^{*+}}$ D, Morgan Bruce ${ }^{3 \dagger}$, Joanne E. Simpson ${ }^{4}$, Cathal J. Hannan ${ }^{5}$ and Paul M. Brennan ${ }^{1,6}$

\begin{abstract}
Background: Malignant glioma cell line models are integral to pre-clinical testing of novel potential therapies. Accurate prediction of likely efficacy in the clinic requires that these models are reliable and consistent. We assessed this by examining the reporting of experimental conditions and sensitivity to temozolomide in glioma cells lines.

Methods: We searched Medline and Embase (Jan 1994-Jan 2021) for studies evaluating the effect of temozolomide monotherapy on cell viability of at least one malignant glioma cell line. Key data items included type of cell lines, temozolomide exposure duration in hours ( $\mathrm{hr})$, and cell viability measure $\left(\mathrm{IC}_{50}\right)$.

Results: We included 212 studies from 2789 non-duplicate records that reported 248 distinct cell lines. The commonest cell line was U87 (60.4\%). Only 10.4\% studies used a patient-derived cell line. The proportion of studies not reporting each experimental condition ranged from $8.0-27.4 \%$, including base medium (8.0\%), serum supplementation (9.9\%) and number of replicates (27.4\%). In studies reporting $I C_{50}$, the median value for $U 87$ at $24 \mathrm{~h}, 48 \mathrm{~h}$ and $72 \mathrm{~h}$ was

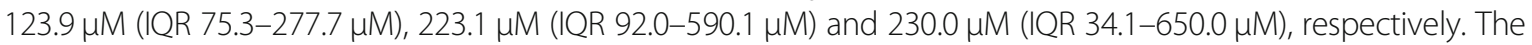
median $\mathrm{IC}_{50}$ at $72 \mathrm{~h}$ for patient-derived cell lines was $220 \mu \mathrm{M}$ (IQR 81.1-800.0 $\left.\mu \mathrm{M}\right)$.

Conclusion: Temozolomide sensitivity reported in comparable studies was not consistent between or within malignant glioma cell lines. Drug discovery science performed on these models cannot reliably inform clinical translation. A consensus model of reporting can maximise reproducibility and consistency among in vitro studies.
\end{abstract}

Keywords: High grade glioma, Glioblastoma, Temodal, Cell culture, GBM

\footnotetext{
* Correspondence: mpoon@ed.ac.uk

${ }^{\dagger}$ Michael TC Poon and Morgan Bruce contributed equally to this work and joint first-authorship.

${ }^{1}$ Cancer Research UK Brain Tumour Centre of Excellence, Edinburgh Cancer Research Centre, Institute of Genetics and Cancer, University of Edinburgh, Edinburgh, UK

${ }^{2}$ Centre for Medical Informatics, Usher Institute, University of Edinburgh, Nine Edinburgh BioQuarter, 9 Little France Road, Edinburgh, UK

Full list of author information is available at the end of the article
}

(C) The Author(s). 2021 Open Access This article is licensed under a Creative Commons Attribution 4.0 International License, which permits use, sharing, adaptation, distribution and reproduction in any medium or format, as long as you give appropriate credit to the original author(s) and the source, provide a link to the Creative Commons licence, and indicate if changes were made. The images or other third party material in this article are included in the article's Creative Commons licence, unless indicated otherwise in a credit line to the material. If material is not included in the article's Creative Commons licence and your intended use is not permitted by statutory regulation or exceeds the permitted use, you will need to obtain permission directly from the copyright holder. To view a copy of this licence, visit http://creativecommons.org/licenses/by/4.0/ The Creative Commons Public Domain Dedication waiver (http://creativecommons.org/publicdomain/zero/1.0/) applies to the data made available in this article, unless otherwise stated in a credit line to the data. 


\section{Introduction}

Malignant glioma is the most common primary cancer of the central nervous system [1]. Treatment options vary between types of malignant glioma, but prognosis is poor [2]. Classification depends on histological and molecular features [3]. Glioblastoma, accounting for $60 \%$ of all malignant gliomas, carries the worst outcome with median survival of 6-8 months and 3\% 5-year survival $[2,4,5]$. Standard care has not changed in 15 years and involves surgical resection followed by a combination of radiotherapy and chemotherapy with the alkylating agent temozolomide [6]. No human clinical trials to date have demonstrated superior treatment effect with a novel therapeutic agent [7], so there is an urgent need to examine the processes of drug discovery.

Cancer drug discovery utilises pre-clinical models to predict the likely effect of a novel compound on cancer tissue. In vitro cell cultures are readily available from repositories [8] and in studies of malignant glioma, temozolomide is frequently used as the comparative therapeutic agent because of its role in standard care. The robustness of this strategy depends on the reproducibility of temozolomide sensitivity in vitro, which may be affected by variations in experimental conditions $[9,10]$. This is critical to experimental design and to data interpretation, so requires adequate reporting.

Transparency in clinical research has received increasing attention in the past two decades. There has been an expansion of reporting guidelines for clinical studies facilitated by the Enhancing the Quality and Transparency Of health Research (EQUATOR) network [11]. Most guidelines relate to clinical research, but the Animal Research: Reporting of In Vivo Experiments (ARRIVE) guidelines are relevant to pre-clinical animal models [12]. However, there are currently no standardised reporting guidelines for cell culture studies. Evaluation of the experimental conditions and drug sensitivity of cell lines in published reports may provide an insight into the reproducibility and consistency in these models. The aim of this review was to quantify the variability and reporting of experimental conditions in in vitro studies using malignant glioma cell lines and to assess variations in temozolomide sensitivity.

\section{Methods}

There is no suitable repository for systematic review of in vitro studies in which our protocol could be registered. We followed the Preferred Reporting Items for Systematic Reviews and Meta-Analyses (PRISMA) guidelines.

\section{Eligibility criteria}

We included studies published after 1993 that evaluated the effect of temozolomide monotherapy on cell viability of at least one malignant glioma cell line. The evaluation of temozolomide could be a control experiment within a study. There was no limit on the type of cell viability measure. We excluded studies that utilised a drugresistant cell line, a modified preparation of temozolomide, or an animal model. Studies using cell line-based xenotransplant animal models or reporting outcome measures other than cell viability were excluded.

\section{Information sources}

We searched Ovid Medline and Embase between January 1994 and January 2021 using a combination of search terms relating to gliomas, cell lines, temozolomide, and cell death. The full search strategies are available in Supplementary Material. Our search date was on 28th January 2021. There was no hand search or search in the grey literature.

\section{Study selection \& data extraction}

The online tool Covidence was our platform for conducting the primary screening and data extraction in this review. We applied the built-in deduplication function on the platform to records retrieved from our database search. One reviewer (MB) screened titles and abstracts of all records, of which $10 \%$ excluded records were reviewed by a second reviewer (MTCP). We used the same review approach for full-text eligibility assessment. One reviewer (MB) extracted data from all eligible articles and a second reviewer (MTCP) independently extract data from $40 \%$ of these studies. We resolved disagreements by discussion between the two reviewers or by seeking resolution from a third reviewer (PMB).

\section{Data items}

We collected data on study characteristics, experimental setup and cell viability measures. Study characteristics included year of publication, country of primary affiliation, the primary aim of study, and types of cell lines used. 'Primary aim of study' had three categories: "therapeutic evaluation" referred to studies comparing the effects on cell lines of another therapeutic agent alone against temozolomide; "pathway modification" referred to studies that altered cellular pathways with a molecularly targeted compound and assessed the effect of temozolomide on the cell lines; "gene or protein measurement" referred to studies that measured levels of molecular markers in response to temozolomide. We categorised cell lines into human cell lines, murine cell lines, and cancer stem cell-like patient-derived cell lines. Patient-derived cell lines were developed from patients with malignant glioma at the investigators' institute. Experimental setup data included temozolomide concentration, temozolomide exposure duration, base medium, addition of serum, cell density, cell passage number, use 
of hypoxic environment, and temperature and percentage of carbon dioxide in the ambient incubator environment.

Cell viability was our outcome of interest. Data on cell viability included the assay, quantification technique used and cell viability measurement. Cell viability assays included 3-(4,5-dimethylthiazolyl-2)-2,5-diphenyl-2Htetrazolium bromide (MTT), sulphondamine B (SRB), annexin $\mathrm{V}$, propium iodide (PI), trypan blue, bromodeoxyuridine (BrdU) and luciferase-based techniques. Quantification techniques included flow cytometry, colorimetric or fluorometric plate reader, microscopy with manual counting, and microscopy with automated counting. Where reported, we collected drug sensitivity measures on half-maximal inhibitory concentration $\left(\mathrm{IC}_{50}\right)$, half-maximal effective concentration $\left(\mathrm{EC}_{50}\right)$, dose reduces initial population to $10 \%\left(\mathrm{LD}_{10}\right)$, dose reduces survival number of cells to $37 \%\left(\mathrm{D}_{37}\right)$, approximate concentration of drug tolerated without lethality (DT), and median-effect dose (Dm). To assess the internal validity, we assessed whether a study reported the number of replicate plates and the number of replicates per plate.

\section{Risk of bias}

There was no suitable risk of bias tool for the type of studies included in this review. The completeness of reporting of the data items described above was instead used to indicate the transparency of the studies to permit summarisation of comparable studies.

\section{Data synthesis}

We used descriptive statistics to summarise the data items. Our reporting of temozolomide sensitivity measures was stratified for the two most common cell lines (U87, U251) and patient-derived cell lines. We divided studies into groups that had the same cell lines exposed to temozolomide for the same duration, in a nonhypoxic environment, and reported the same drug sensitivity measures. We tested the homogeneity of variances in temozolomide sensitivity across cell lines using Levene's and Fligner-Killeen tests. There was no plan for meta-analysis because studies were anticipated to be heterogeneous and drug sensitivity measures without a measure of variance are not amenable to meta-analysis. These reasons also precluded the assessment of reporting bias. We performed all analyses in $\mathrm{R}$ version 4.1.0 using 'tidyverse' (v1.3.1), 'gtsummary' (v1.4.1), and 'car' (v.3.0-10) packages.

\section{Results}

\section{Study selection and characteristics}

Our search retrieved 3586 records. After removing 797 duplicates, 2789 records underwent title and abstract screening, of which 1532 studies had full-text eligibility assessment. We included 212 eligible studies ${ }^{\mathrm{s} 1-213}$ using malignant glioma cell lines that reported cell viability measures associated with temozolomide (Fig. 1). Of the 1320 studies excluded at full eligibility assessment, the primary reason for exclusion for 717 studies was no reporting of cell viability measures.

Of all the included studies, 140 (66.0\%) were published in or after 2015. Countries accounting for over $10 \%$ of the included studies were China (35.4\%) and the United States (17.9\%). The proportion of studies published in or after 2015 from China and from the United States was 78.9 and $57.9 \%$, respectively. Most studies (85.4\%) evaluated therapeutic agents against temozolomide in their cell lines as the primary aim. There were 19 (9.0\%) studies measuring gene or protein levels in their cell lines in response to temozolomide and 12 (5.6\%) studies assessed the cell line response to temozolomide after modification of a cellular pathway. A human glioma cell line was at least one of the cell lines used in 193 (91.0\%) studies. Twenty-three $(10.8 \%)$ studies used at least one murine cell line and $22(10.4 \%)$ studies used at least one patient-derived cell line (Table 1). Most studies (77.4\%) used two or more cell lines in their studies.

\section{Cell lines \& experimental setup}

Of 750 cell lines reported in the 212 included studies, there were 248 distinct cell lines. The three most used cell lines were U87 (60.4\%), U251 (41.0\%), and T98G (26.4\%). Their use did not appear to change over time (Table 1). Patient-derived cell lines were used in $7.8 \%$ studies published in 2018 or after compared with over $12.5 \%$ in studies published before 2015. There were 130 distinct patient-derived cell lines reported in 22 studies.

Dulbecco's Modified Eagle Medium (DMEM) was the commonest base medium, used in 142 (66.5\%) studies (Table 2). There were $23(10.8 \%)$ studies that used a customised medium and $17(8.0 \%)$ studies did not report the type of base medium used. Reporting of carbon dioxide concentration and temperature was missing in 54 (25.5\%) and 52 (24.5\%) studies, respectively. Five (2.3\%) studies utilised a hypoxic environment, but 54 (25.5\%) studies did not report the oxygen specification. Cell density was frequently reported in 154 (72.6\%) studies. Cell passage number was reported in only 16 (7.5\%) studies.

\section{Specification of temozolomide use}

The range of temozolomide concentrations used in determining drug sensitivity was not determinable from 30 (14.2\%) studies (Table 3 ). The median lower limit of temozolomide concentration was $0.1 \mu \mathrm{M}$ (range $0-$ $6250 \mu \mathrm{M}$, interquartile range [IQR] $0-10 \mu \mathrm{M})$ and the median upper limit was $800 \mu \mathrm{M}$ (range $30-400,000 \mu \mathrm{M}$, IQR 250-1266 $\mu \mathrm{M})$. A single temozolomide exposure 


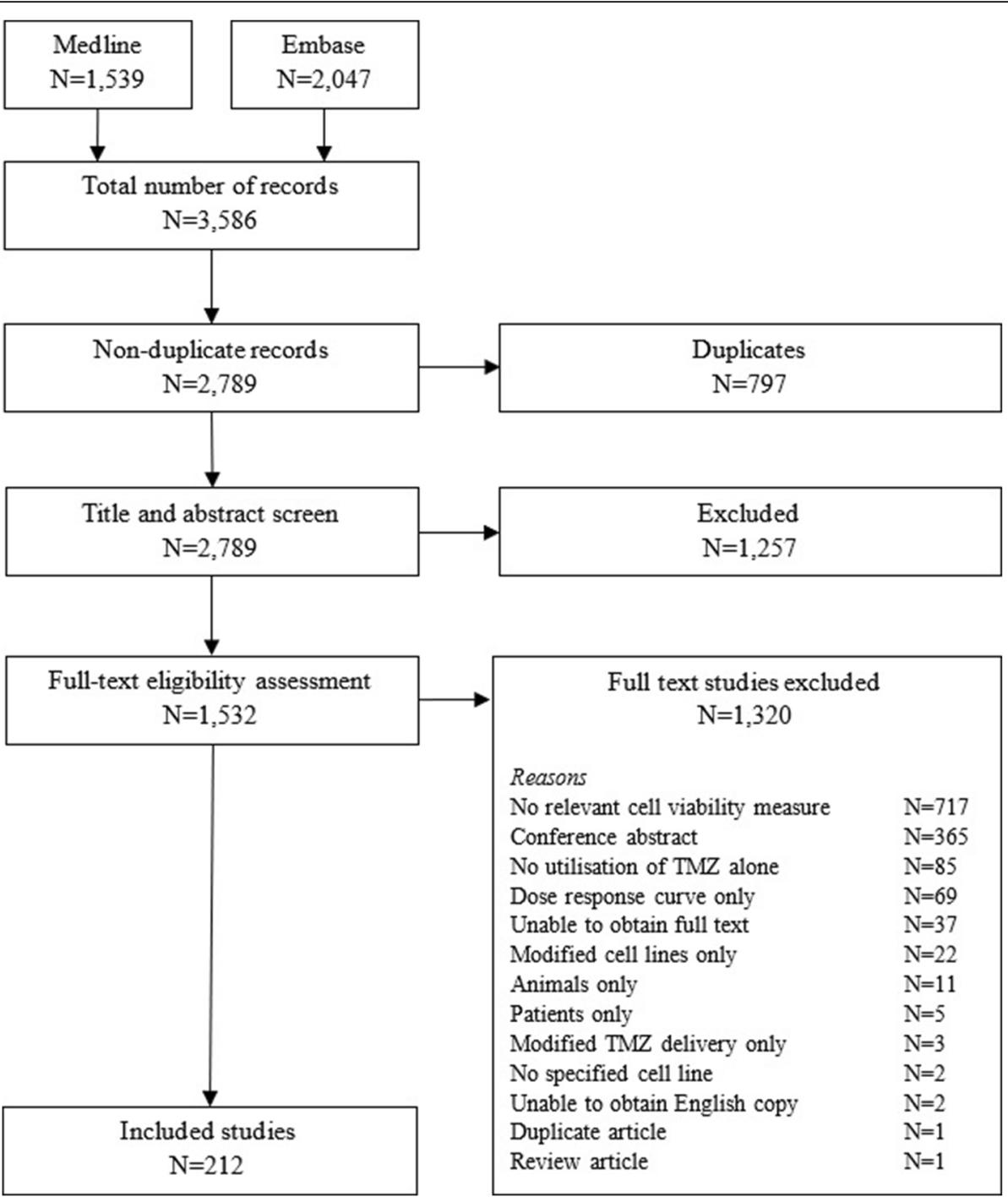

Fig. 1 Flowchart describing study selection for inclusion

time was not reported in 47 (22.2\%) studies, of which 38 studies instead reported a range of exposure times. The three most common temozolomide exposure times were $72 \mathrm{~h}(29.1 \%), 48 \mathrm{~h}(16.7 \%)$, and $24 \mathrm{~h}(11.8 \%)$.

\section{Cell viability methods and drug sensitivity measures}

MTT was the most common primary cell viability assay, which was used in 95 (44.8\%) studies (Table 3). Thirty-five (16.5\%) studies used the Cell Counting Kit-8, another colorimetric assay. Five (2.4\%) studies did not specify their cell viability assays. A plate reader was used in 124 (58.5\%) studies and 45 (21.2\%) studies did not specify their quantification techniques for measuring cell viability. Among our pre-specified drug sensitivity measures, 182 (85.8\%) studies reported $\mathrm{IC}_{50}$ of temozolomide for their cell lines. The other drug sensitivity measures each had fewer than 10 studies reporting them.

\section{Temozolomide sensitivity}

We examined studies together that used the same temozolomide exposure time and reported $\mathrm{IC}_{50}$ of temozolomide for their cell lines (Fig. 2). Descriptive statistics here relate to cell lines at each exposure duration that had $\geq 10$ measurements of temozolomide $\mathrm{IC}_{50}$. The median $\mathrm{IC}_{50}$ of temozolomide for U87 cell line at $24 \mathrm{~h}, 48 \mathrm{~h}$ and $72 \mathrm{~h}$ was $123.9 \mu \mathrm{M}$ (IQR 75.3-277.7 $\mu \mathrm{M}$ ), 223.1 $\mu \mathrm{M}$ (IQR 92.0-590.1 $\mu \mathrm{M}$ ) and $230.0 \mu \mathrm{M}$ (IQR 34.1-650.0 $\mu \mathrm{M}$ ), respectively (Fig. $2 \mathrm{~A})$. In $\mathrm{U} 251$ cell line, the median temozolomide $\mathrm{IC}_{50}$ at $48 \mathrm{~h}$ and $72 \mathrm{~h}$ was $240.0 \mu \mathrm{M}$ (IQR 34.0$338.5 \mu \mathrm{M}$ ) and $176.50 \mu \mathrm{M}$ (IQR $30.0-470.0 \mu \mathrm{M}$ ), respectively. The median $\mathrm{IC}_{50}$ of temozolomide at $72 \mathrm{~h}$ for T98G and patient-derived cell lines was $438.3 \mu \mathrm{M}$ (IQR 232.4-649.5 $\mu \mathrm{M}$ ) and $220 \mu \mathrm{M}$ (IQR 81.1$800.0 \mu \mathrm{M})$, respectively. 
Table 1 Characteristics of malignant glioma cell line reported in 212 included studies

\begin{tabular}{|c|c|c|c|c|}
\hline \multirow[t]{2}{*}{ Characteristics } & \multirow{2}{*}{$\begin{array}{l}\text { Overall } \\
N=212\end{array}$} & \multicolumn{3}{|c|}{ Year of publication } \\
\hline & & $\begin{array}{l}\text { Before } 2015 \\
N=72\end{array}$ & $\begin{array}{l}2015-2017 \\
N=63\end{array}$ & $\begin{array}{l}2018 \text { or after } \\
N=77\end{array}$ \\
\hline \multicolumn{5}{|l|}{ Type of cell line } \\
\hline Human glioma cell line(s) & $193(91.1 \%)$ & $65(90.3 \%)$ & 57 (90.5\%) & 71 (92.2\%) \\
\hline Murine glioma cell line(s) & $23(10.8 \%)$ & $5(6.9 \%)$ & $6(9.5 \%)$ & $12(15.4 \%)$ \\
\hline Patient-derived cell line(s) & $22(10.4 \%)$ & $9(12.5 \%)$ & $7(11.1 \%)$ & $6(7.7 \%)$ \\
\hline \multicolumn{5}{|l|}{ Number of cell lines used } \\
\hline One & $48(22.6 \%)$ & $14(19.4 \%)$ & $15(23.8 \%)$ & $19(24.7 \%)$ \\
\hline Two & 74 (34.9\%) & 19 (26.4\%) & $26(41.3 \%)$ & $29(37.7 \%)$ \\
\hline Three or more & $90(42.5 \%)$ & 39 (54.2\%) & $22(34.9 \%)$ & $29(37.7 \%)$ \\
\hline \multicolumn{5}{|l|}{ Ten commonest cell lines } \\
\hline U87 & $129(60.4 \%)$ & $47(65.3 \%)$ & 37 (58.7\%) & $44(57.1 \%)$ \\
\hline U251 & $87(41.0 \%)$ & $24(33.3 \%)$ & 31 (49.2\%) & $33(41.6 \%)$ \\
\hline T98G & $56(26.4 \%)$ & $25(34.7 \%)$ & $11(17.5 \%)$ & $20(26.0 \%)$ \\
\hline A172 & $29(13.7 \%)$ & $8(11.1 \%)$ & $11(17.5 \%)$ & $10(13.0 \%)$ \\
\hline U373 & $27(12.7 \%)$ & $15(20.8 \%)$ & $6(9.5 \%)$ & $6(7.8 \%)$ \\
\hline U138 & $26(12.3 \%)$ & $15(20.8 \%)$ & $6(9.5 \%)$ & $5(6.5 \%)$ \\
\hline LN229 & $22(10.4 \%)$ & 7 (9.7\%) & $4(6.3 \%)$ & $11(14.3 \%)$ \\
\hline C6 & $20(9.4 \%)$ & $5(6.9 \%)$ & $6(9.5 \%)$ & $9(11.7 \%)$ \\
\hline LN18 & $13(6.6 \%)$ & $6(8.3 \%)$ & $2(3.2 \%)$ & $5(6.5 \%)$ \\
\hline U118 & 14 (6.6\%) & 5 (6.9\%) & 5 (7.9\%) & $4(5.2 \%)$ \\
\hline
\end{tabular}

The asymmetrical distribution of the $\mathrm{IC}_{50}$ values demonstrated in Fig. 2A may be caused by the differing experimental conditions. To examine for the source(s) of this variation in $\mathrm{IC}_{50}$, we then included studies that used a normoxic culture environment (excluding hypoxic culture condition) and that used MTT as the cell viability assay, the most common composite conditions. The $\mathrm{IC}_{50}$ was $155.1 \mu \mathrm{M}$ (IQR $37.8-640.5 \mu \mathrm{M}$ ) for U251 cell line at $48 \mathrm{~h}$ and $230.0 \mu \mathrm{M}$ (IQR $58.0-650.0 \mu \mathrm{M}$ ) for U87 cell line at $72 \mathrm{~h}$ (Fig. 2B), compared to $240.0 \mu \mathrm{M}$ and $230.0 \mu \mathrm{M}$ in the previous analysis of U251 and U87, respectively, at the same time points. The interquartile ranges of the $\mathrm{IC}_{50}$ from more homogeneous studies and from unrestricted studies were similar. Tests for homogeneity did not demonstrate evidence of a difference in $\mathrm{IC}_{50}$ variances across cell lines exposed to temozolomide for $72 \mathrm{~h}$ (Levene's test: $p=0.237$; Fligner-Killeen test: $p=0.346)$.

\section{Discussion}

This systematic review identified 213 studies using cell culture models of malignant gliomas reporting drug sensitivity to temozolomide. Over 700 studies were excluded because they did not report cell viability measures. There were a wide variety of cell lines, and we did not observe an increase over time in patient-derived cell lines despite the implications of the cancer stem cell hypothesis for glioma biology. The reporting of experimental conditions and temozolomide specifications were variable, which made interpretation difficult. Temozolomide sensitivity was not consistent within each cell line. Furthermore, the range of concentrations used across the selected publications is not physiologically or clinically relevant to glioblastoma treatment (approximately 30-50uM in tumour and plasma [13]). This has implications for conduct and interpretation of drug discovery.

Sampling variation of temozolomide sensitivity in the same cell lines between studies should produce a symmetrical distribution of $\mathrm{IC}_{50}$ around the median. The asymmetrical distributions of $\mathrm{IC}_{50}$ in each cell line (Fig. 2A) suggested additional contributors to inconsistency other than sampling variations. While further matching of experimental conditions (Fig. 2B) reduced the asymmetry, the residual asymmetry indicated that inconsistency resulted from differences in unmeasured experimental conditions and in cell behaviours in each cell line. Issues with cultured malignant glioma cell lines are not new. Serum supplementation in classic cell lines has been shown to induce astrocytic differentiation resulting in transcriptional and epigenomic changes that do not reflect the human disease $[14,15]$. There are further problems with misidentification and cross-contamination $[16,17]$. These limitations 
Table 2 Experimental design of 212 included studies

\begin{tabular}{|c|c|}
\hline Characteristics & $N=212$ \\
\hline \multicolumn{2}{|l|}{ Base medium } \\
\hline DMEM & $141(66.5 \%)$ \\
\hline Customised media & $23(10.8 \%)$ \\
\hline Eagle minimal essential medium & $18(8.5 \%)$ \\
\hline DMEM/F12 & $11(5.2 \%)$ \\
\hline Neurobasal & $2(0.9 \%)$ \\
\hline Unspecified & $17(8.0 \%)$ \\
\hline \multicolumn{2}{|l|}{ Serum supplementation } \\
\hline Yes & $190(89.6 \%)$ \\
\hline No & $1(0.4 \%)$ \\
\hline Unknown & $21(9.9 \%)$ \\
\hline \multicolumn{2}{|l|}{ Carbon dioxide (\%) } \\
\hline 5 & $156(73.6 \%)$ \\
\hline 6 & $1(0.5 \%)$ \\
\hline 10 & $1(0.5 \%)$ \\
\hline Unknown & $54(25.5 \%)$ \\
\hline \multicolumn{2}{|l|}{ Temperature } \\
\hline $37^{\circ} \mathrm{C}$ & $160(75.5 \%)$ \\
\hline Unknown & $52(24.5 \%)$ \\
\hline \multicolumn{2}{|l|}{ Hypoxic condition } \\
\hline Used & $5(2.4 \%)$ \\
\hline Unknown & $54(25.5 \%)$ \\
\hline \multicolumn{2}{|l|}{ Other methodological reporting } \\
\hline Cell density & $154(72.6 \%)$ \\
\hline Number of cell passage & $16(7.5 \%)$ \\
\hline Number of replicates & $58(27.4 \%)$ \\
\hline Number of plate replicates & $42(19.8 \%)$ \\
\hline
\end{tabular}

DMEM Dulbecco's Modified Eagle Medium, DMEM/F12 Dulbecco's Modified Eagle Medium/Nutrient Mixture F-12

can contribute to an explanation of our findings of cell lines having inconsistent temozolomide sensitivity. Drug discovery science performed on these incomparable and nonrepresentative malignant glioma models cannot reliably inform clinical translation.

Although there was no apparent increase in its use, about a quarter of the included studies used patientderived glioma cell lines, so-called stem-like cancer cells. The purported advantage of these cell is their ability to retain genetics and transcriptional characteristics of the human disease better than standard serum grown human cell lines $[14,18,19]$. Examining the effect of novel compounds on these stem-like cells may be more clinically relevant. However, there was no evidence of a smaller (or larger) variance of temozolomide sensitivity compared with other human cell lines. Better understanding of the molecular characteristics of tumour cells as well as experimental conditions in studies using
Table 3 Temozolomide specification and methods for measuring cell viability

\begin{tabular}{|c|c|}
\hline Characteristics & $N=212$ \\
\hline \multicolumn{2}{|l|}{ Temozolomide concentration ( $\mu \mathrm{M})$} \\
\hline Lower range $(I Q R)^{\mathrm{a}}$ & $0(0-10)$ \\
\hline Upper range $(\mathrm{IQR})^{\mathrm{a}}$ & $800(250.0-1266)$ \\
\hline Unspecified & $30(14.2 \%)$ \\
\hline \multicolumn{2}{|l|}{ Temozolomide exposure time } \\
\hline$<24$ hours & $8(3.8 \%)$ \\
\hline 24 hours & $24(11.3 \%)$ \\
\hline 48 hours & $34(16.0 \%)$ \\
\hline 72 hours & $59(27.8 \%)$ \\
\hline 96 hours & $15(7.1 \%)$ \\
\hline$>96$ hours & $25(11.8 \%)$ \\
\hline Range of time & $38(17.9 \%)$ \\
\hline Unspecified & $9(4.2 \%)$ \\
\hline \multicolumn{2}{|l|}{ Cell viability assay } \\
\hline MTT & $95(44.8 \%)$ \\
\hline CCK-8 & $35(16.5 \%)$ \\
\hline MTS & $11(5.2 \%)$ \\
\hline Trypan blue & $11(5.2 \%)$ \\
\hline Other & $55(25.9 \%)$ \\
\hline Unspecified & $5(2.4 \%)$ \\
\hline \multicolumn{2}{|l|}{ Method for cell viability quantification } \\
\hline Plate reader & $124(58.5 \%)$ \\
\hline Flow cytometry & $13(6.1 \%)$ \\
\hline Microscopy and manual counting & $11(5.2 \%)$ \\
\hline Microscopy and automated counting & $3(1.4 \%)$ \\
\hline Technique in a reference/manual & $16(7.5 \%)$ \\
\hline Unspecified & 45 (21.2\%) \\
\hline
\end{tabular}

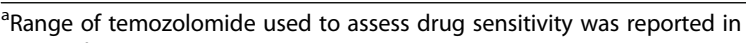
183 studies.

IQR interquartile range, $M T T$ 3-(4,5-dimethylthiazolyl-2)-2,5-diphenyl-2Htetrazolium bromide, CCK-8 Cell Counting Kit-8, MTS MTT with phenazine methosulfate

patient-derived cell lines can increase comparability and reproducibility between studies. Initiatives that offer molecularly defined and clinically representative patientderived cell lines such as The Human Glioblastoma Cell Culture resource [20] could facilitate more reproducible drug screening.

One of the challenges in summarising temozolomide sensitivities from the included studies was the suboptimal reporting of key experimental conditions. These conditions, such as cell density and carbon dioxide levels, can affect the accuracy of cell viability assay readout [21]. Guidelines for the conduct of using cell lines for biomedical research [22] relate to best practice in the standard operating procedure within each laboratory. While some aspects of these guidelines are relevant to 


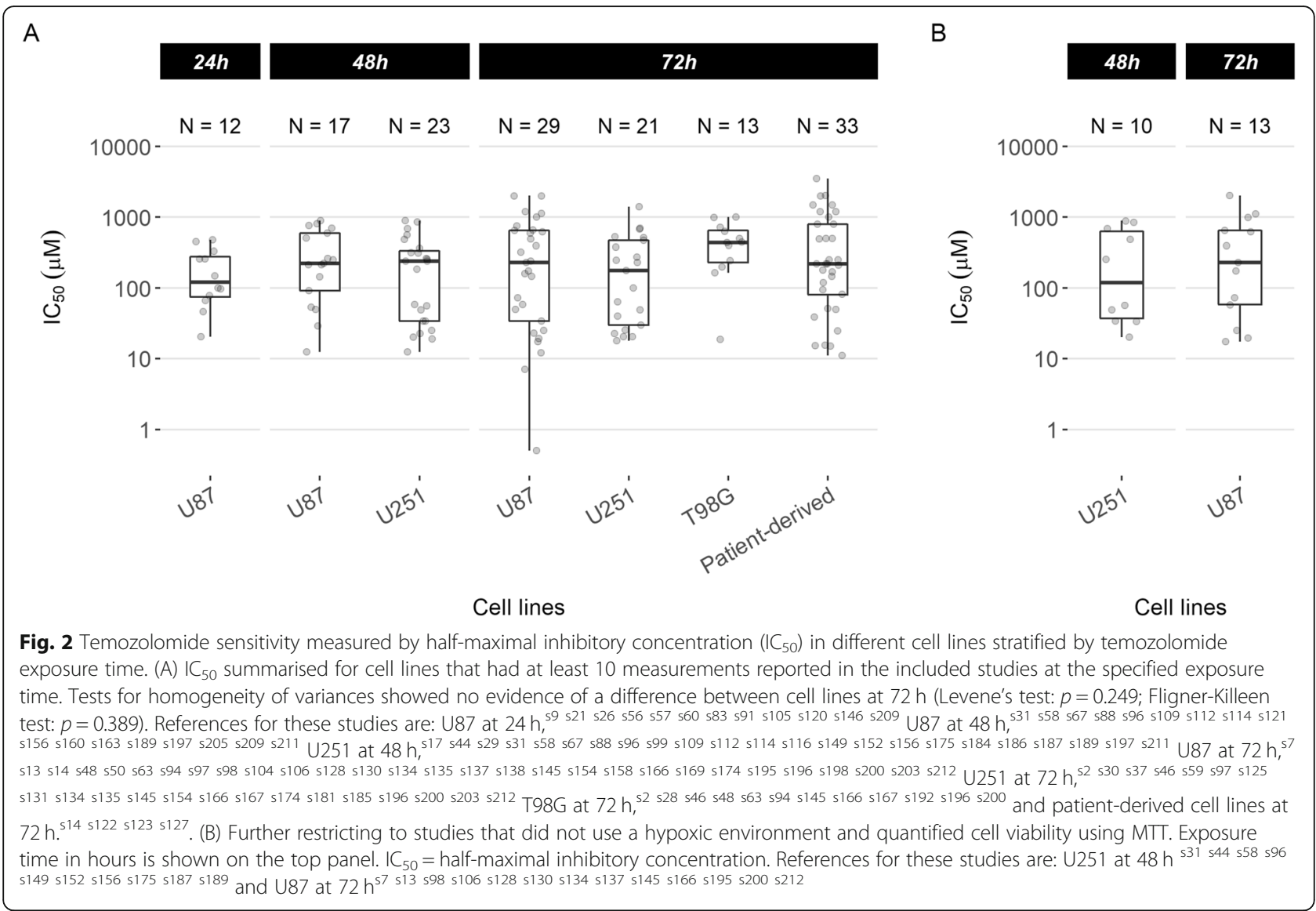

the consistency of cancer cell line behaviours, they do not provide a framework for reporting experimental conditions that could affect compound sensitivity. In clinical research, the EQUATOR network has facilitated the development of tailored reporting guidelines specific to different study designs. The earliest guideline was the Consolidated Standards of Reporting Trials (CONSORT) statement [23], which has been cited for over 8000 times since its first version published 25 years ago [24]. The conception of this guideline stemmed from a unanimous opinion from a group of clinical research experts that the quality of reports of randomised controlled trials was in adequate. Our findings from malignant glioma cell line studies indicate similar concerns about the reporting quality in drug discovery studies using cancer cell lines. Variations in experimental design may not be fully captured in a standardised reporting guideline. However, without reproducibility and predictability, data interpretation is unreliable. The issue of reproducibility in preclinical animal models that drove the development of ARRIVE guidelines [12]. What we have in cell line studies should prompt development of guidelines for transparency, consistency and reproducibility.

\section{Strengths and limitations}

This systematic review had a comprehensive search that included all malignant glioma cell lines with their respective drug sensitivity to temozolomide. The vast number of cell lines summarised provided an overview of in vitro studies investigating malignant gliomas. Findings of our review also described the methodological practice and reporting associated with the assessment of cell viability to therapeutic agents. All these are important considerations for better design comparable studies in the future.

We drew our results only from malignant glioma cell line models. There are other related experimental models such as drug resistant cell lines, genetically modified cell lines, tumour spheres, organoids and xenotransplant models [10]. Our findings are likely to be relevant and generalisable to other models because sources of heterogeneity remain uncontrolled and there are more margins of errors associated with other experimental models. The need for consistency and reproducibility apply to all models. There may be other cellular or experimental features that affect cell viability that were not assessed here. These may include MGMT promoter 
methylation, isocitrate dehydrogenase (IDH) mutations, telomerase reverse transcriptase (TERT) mutations, $1 \mathrm{p} /$ $19 \mathrm{q}$ co-deletion and alpha-thalassemia mental retardation syndrome $(A T R X)$ mutations [25]. While it would be useful to summarise, there is little consistent evidence to support their role in cell viability and they are very unlikely to be reported in non-patient-derived cell lines. These specific mutations are unlikely to contribute to the observed variability in classical cell lines which should each, in theory, share the same genetic background, although other genetic and epigenetic changes may have been acquired in culture over time [26]. Studies using patient-derived cell lines often reported patient characteristics, which could partially explain the drug sensitivity variations observed. These cell lines are more likely to be glioma stem cell lines, which are more heterogeneous. The small number of cell lines with comparable experimental conditions would prevent meaningful subgroup analyses to investigate additional the effect of additional characteristics on cell viability.

\section{Conclusions}

Temozolomide sensitivity reported in comparable studies was not consistent between and within individual malignant glioma cell lines. This raises concerns about the reliability and translational value of drug discovery studies that use glioma cell lines. Appraisal and interpretation of the results can only be achievable if studies report key experimental conditions. While there will be variations of opinion on what the optimal design is, a consensus model of a reporting structure is the only rational way to maximise the yield from in vitro studies to find novel therapies for our patients.

\begin{abstract}
Abbreviations
ARRIVE: Animal Research: Reporting of In Vivo Experiments; ATRX: Alphathalassemia mental retardation syndrome; BrdU: Bromodeoxyuridine; CONSORT: Consolidated Standards of Reporting Trials; $\mathrm{D}_{37}$ : Dose reduces survival number of cells to 37\%; DT: Approximate concentration of drug tolerated without lethality; Dm: Median-effect dose; $\mathrm{EC}_{50}$ : Half-maximal effective concentration; EQUATOR: Enhancing the Quality and Transparency Of health Research; $I_{50}$ : Half-maximal inhibitory concentration; IDH: Isocitrate dehydrogenase; $\mathrm{LD}_{10}$ : Dose reduces initial population to 10\%; MTT: 3-(4,5dimethylthiazolyl-2)-2,5-diphenyl-2H-tetrazolium bromide; PI: Propium iodide;
\end{abstract} SRB: Sulphondamine B; TERT: Telomerase reverse transcriptase

\section{Supplementary Information}

The online version contains supplementary material available at https://doi. org/10.1186/s12885-021-08972-5.

Additional file 1.

\section{Acknowledgements}

A preprint of this work is archived in MedRxiv (https://doi.org/10.1101/2021. 06.29.21259733). We would like to thank colleagues at the Collaborative Approach to Meta-Analysis and Review of Animal Data from Experimental Studies (CAMARADES) for providing valuable feedback on our work.

\section{Authors' contributions}

Study conceptualisation: MTCP, MB, PMB. Protocol design: MTCP, MB, CH, PMB. Abstract screening, eligibility assessment, data extraction, data analyses: MTCP, MB. Interpretation of data: MTCP, MB, JES, CH, PMB. Drafting the manuscript: MTCP and MB. Critical revision of manuscript: JES, CH, PMB. All authors have read and approved the final manuscript.

\section{Funding}

JES is supported by Cancer Research UK (C52370/A21586). MTCP is supported by Cancer Research UK Brain Tumour Centre of Excellence Award (C157/A27589). The funding bodies played no role in the design of the study and collection, analysis, and interpretation of data and in writing the manuscript.

\section{Availability of data and materials}

The dataset generated and analysed during the current study is available in the Open Science Framework (osf.io) repository (https://doi.org/10.17605/ OSF.IO/U8WHR)

\section{Declarations}

Ethics approval and consent to participate

Not applicable.

\section{Consent for publication}

Not applicable.

\section{Competing interests}

The authors declare no conflict of interest.

\section{Author details}

${ }^{1}$ Cancer Research UK Brain Tumour Centre of Excellence, Edinburgh Cancer Research Centre, Institute of Genetics and Cancer, University of Edinburgh, Edinburgh, UK. ${ }^{2}$ Centre for Medical Informatics, Usher Institute, University of Edinburgh, Nine Edinburgh BioQuarter, 9 Little France Road, Edinburgh, UK ${ }^{3}$ Biological Sciences, Edinburgh Medical School, University of Edinburgh, Edinburgh, UK. ${ }^{4}$ Cancer Research UK Edinburgh Centre, Institute of Genetics and Cancer, University of Edinburgh, Edinburgh, UK. ${ }^{5}$ Department of Neurosurgery, Manchester Centre for Clinical Neurosciences, Manchester, UK. ${ }^{6}$ Centre for Clinical Brain Sciences, University of Edinburgh, Edinburgh, UK.

Received: 10 October 2021 Accepted: 5 November 2021

Published online: 18 November 2021

\section{References}

1. GBD. Brain and other CNS Cancer collaborators (2019) global, regional, and national burden of brain and other CNS cancer, 1990-2016: a systematic analysis for the global burden of disease study 2016. Lancet Neurol. 2016; 18(4):376-93. https://doi.org/10.1016/S1474-4422(18)30468-X.

2. Ostrom QT, Patil N, Cioffi G, Waite K, Kruchko C, Barnholtz-Sloan JS. CBTRUS statistical report: primary brain and other central nervous system tumors diagnosed in the United States in 2013-2017. NeuroOncology. 2020;22:iv1-iv96.

3. Louis DN, Perry A, Reifenberger G, von Deimling A, Figarella-Branger D, Cavenee WK, et al. The 2016 World Health Organization classification of tumors of the central nervous system: a summary. Acta Neuropathol (Berl). 2016:131(6):803-20. https://doi.org/10.1007/s00401-016-1545-1.

4. Poon MTC, Sudlow CLM, Figueroa JD, Brennan PM. Longer-term ( $\geq 2$ years) survival in patients with glioblastoma in population-based studies pre- and post-2005: a systematic review and meta-analysis. Sci Rep. 2020;10(1):11622. https://doi.org/10.1038/s41598-020-68011-4.

5. Brodbelt A, Greenberg D, Winters T, Williams M, Vernon S. Collins VP, (UK) National Cancer Information Network Brain Tumour Group (2015) glioblastoma in England: 2007-2011. Eur J Cancer Oxf Engl. 1990;51(4):53342. https://doi.org/10.1016/j.ejca.2014.12.014.

6. Stupp R, Mason WP, van den Bent MJ, Weller M, Fisher B, Taphoorn MJB, et al. Radiotherapy plus concomitant and adjuvant temozolomide for glioblastoma. N Engl J Med. 2005;352(10):987-96. https://doi.org/10.1056/ NEJMoa043330 
7. Taslimi S, Ye VC, Zadeh G. Lessons learned from contemporary glioblastoma randomized clinical trials through systematic review and network metaanalysis: part 2 newly diagnosed disease. Neuro Oncol Adv. 2021;3:vdab028.

8. ATCC ATCC: The Global Bioresource Center. https://www.atcc.org/. Accessed 23 Jun 2021.

9. Ledur PF, Onzi GR, Zong H, Lenz G. Culture conditions defining glioblastoma cells behavior: what is the impact for novel discoveries? Oncotarget. 2017;8(40):69185-97. https://doi.org/10.18632/oncotarget.20193.

10. Robertson FL, Marqués-Torrejón M-A, Morrison GM, Pollard SM. Experimental models and tools to tackle glioblastoma. Dis Model Mech. 2019;12:dmm040386.

11. Altman DG, Simera I. A history of the evolution of guidelines for reporting medical research: the long road to the EQUATOR network. J R Soc Med. 2016;109(2):67-77. https://doi.org/10.1177/0141076815625599.

12. Percie du Sert N, Hurst V, Ahluwalia A, et al. The ARRIVE guidelines 2.0: Updated guidelines for reporting animal research. PLoS Biol. 2020;18: e3000410.

13. Beier D, Schriefer B, Brawanski K, Hau P, Weis J, Schulz JB, et al. Efficacy of clinically relevant temozolomide dosing schemes in glioblastoma cancer stem cell lines. J Neuro-Oncol. 2012;109(1):45-52. https://doi.org/10.1007/s11 060-012-0878-4.

14. Lee J, Kotliarova S, Kotliarov Y, Li A, Su Q, Donin NM, et al. Tumor stem cells derived from glioblastomas cultured in bFGF and EGF more closely mirror the phenotype and genotype of primary tumors than do serum-cultured cell lines. Cancer Cell. 2006;9(5):391-403. https://doi.org/10.1016/j.ccr.2006. 03.030.

15. Peng D, Gleyzer R, Tai W-H, Kumar P, Bian Q, Isaacs B, et al. Evaluating the transcriptional fidelity of cancer models. Genome Med. 2021;13(1):73. https://doi.org/10.1186/s13073-021-00888-w.

16. Allen $M$, Bjerke $M$, Edlund $H$, Nelander $S$, Westermark B. Origin of the U87MG glioma cell line: good news and bad news. Sci Transl Med. 2016;8: 354 re3.

17. American Type Culture Collection Standards Development Organization Workgroup ASN-0002. Cell line misidentification: the beginning of the end. Nat Rev Cancer. 2010;10(6):441-8. https://doi.org/10.1038/nrc2852.

18. Pollard SM, Yoshikawa K, Clarke ID, Danovi D, Stricker S, Russell R, et al. Glioma stem cell lines expanded in adherent culture have tumor-specific phenotypes and are suitable for chemical and genetic screens. Cell Stem Cell. 2009:4(6):568-80. https://doi.org/10.1016/.stem.2009.03.014.

19. deCarvalho AC, Kim H, Poisson LM, et al. Discordant inheritance of chromosomal and extrachromosomal DNA elements contributes to dynamic disease evolution in glioblastoma. Nat Genet. 2018:50(5):708-17. https://doi.org/10.1038/s41588-018-0105-0.

20. Xie $Y$, Bergström $T$, Jiang $Y$, Johansson $P$, Marinescu VD, Lindberg $N$, et al. The human glioblastoma cell culture resource: validated cell models representing all molecular subtypes. EBioMedicine. 2015;2(10):1351-63. https://doi.org/10.1016/j.ebiom.2015.08.026.

21. Plumb JA, Milroy R, Kaye SB. Effects of the $\mathrm{pH}$ dependence of 3-(4,5dimethylthiazol-2-yl)-2,5-diphenyl-tetrazolium bromide-formazan absorption on chemosensitivity determined by a novel tetrazolium-based assay. Cancer Res. 1989:49(16):4435-40

22. Geraghty RJ, Capes-Davis A, Davis JM, Downward J, Freshney RI, Knezevic I, et al. Guidelines for the use of cell lines in biomedical research. Br J Cancer. 2014;111(6):1021-46. https://doi.org/10.1038/bjc.2014.166.

23. Schulz KF, Altman DG, Moher D, CONSORT Group. CONSORT 2010 statement: updated guidelines for reporting parallel group randomised trials. BMJ. 2010;340:c332.

24. CONSORT Consort - Impact of CONSORT. http://www.consort-statement. org/about-consort/impact-of-consort. Accessed 23 Jun 2021.

25. Aquilanti E, Miller J, Santagata S, Cahill DP, Brastianos PK. Updates in prognostic markers for gliomas. Neuro-Oncology. 2018;20:vii17-26.

26. Torsvik A, Stieber D, Enger P $\varnothing$, Golebiewska A, Molven A, Svendsen A, et al. U-251 revisited: genetic drift and phenotypic consequences of long-term cultures of glioblastoma cells. Cancer Med. 2014;3(4):812-24. https://doi. org/10.1002/cam4.219.

\section{Publisher's Note}

Springer Nature remains neutral with regard to jurisdictional claims in published maps and institutional affiliations.

\section{Ready to submit your research? Choose BMC and benefit from:}

- fast, convenient online submission

- thorough peer review by experienced researchers in your field

- rapid publication on acceptance

- support for research data, including large and complex data types

- gold Open Access which fosters wider collaboration and increased citations

- maximum visibility for your research: over $100 \mathrm{M}$ website views per year

At BMC, research is always in progress.

Learn more biomedcentral.com/submissions 